\title{
RELIGION, CULTURE AND LOCAL WISDOM IN THE DEATH RITUAL OF PONTIANAK MALAY SOCIETY
}

\author{
Sumarman Muhammad Djar'ie and Zaenuddin Hudi Prasojo \\ Pontianak State Institute of Islamic Studies
}

\begin{abstract}
Death is inevitable and will occur to every living creature, including humans no mater what religion or belief they have; however, no one knows for sure when it happens. Humans can only predict death based on indicators that can be seen before it occurs. Still until now, there are many people who attempt to oppose death, even though in the end they have to admit that Allah is the Almighty. Therefore, no wonder if the death is still considered a tragedy rather than the culmination of happiness when humans finally harvest of deeds they have done all their life. In this light, death rituals are often accompanied by the tears of the family of the deceased, even some cry hard to express their pain as someone they love is gone, coupled with the arrival of relatives and acquaintances who mourn, and condolences as well as the phrase "inna lillâh wa inna ilaihi rajiûn". A day of joy has turned into a day of sorrow, although it always ends with kendurian (gathering for remembering the dead), whose excitement is like that of selamatan (communal feast) and syukuran (celebration of thankfulness). This paper tries to present the infiltration of religion and culture in the death ritual in Pontianak Malay community as an object of discussion of local wisdom by using mafhûm mukhâlafah approach, to provide a new understanding of the meaning of death.
\end{abstract}

Keywords: Local Wisdom, Death Ritual, Malay Culture

\section{INTRODUCTION}

The idea of writing this paper originated from a conversation between two middle-aged men that I accidentally heard at a coffee shop near the junction of Jalan Perdamaian - Jalan Karya (SL 0003'57.8” EL 109¹8'04.4”) Pontianak. One of them said that "if you don't have 10 million, don't die first! You'll be sorry for the family that you leave behind". The next conversation, a detailed description of what was said, it came across my mind about a new understanding of death that appeared to have profit value that provides many opportunities for various parties to engage in a ritual of death and take advantage of the family of the dead.

A new understanding of death was reflected on October 2013, when my uncle (my father's brother) died because of old age in Kampung Kapur Parit Mayor, 
Sub-District of East Pontianak, Pontianak City on Monday October 28, 2013 at $9 \mathrm{pm}$ at the age of 73 years. Two days later my cousin (child of my mother's sister) also died of chronic disease in the Soedarso Hospital, Pontianak on Wednesday October 30, 2013 at 8 pm at the age of 45 years. Within 40 days after the death, the family of the deceased had spent tens of millions, far exceeding the target costs I accidentally heard at the coffee shop.

For my cousin's family, such expenses are not a major problem for the death ritual, because the deceased was an only child whose childhood was already accustomed to a life of luxury, and the deceased's father is a rich arowana fish breeder in Putussibau. However, it was not the case for my uncle's the family, who moved from one city to another, in order to find a decent living and sometimes they had to ask for help from the relatives just to meet the daily needs. Socio-economic condition of the family of the deceased is not the main goal in this discussion, because whoever they are and whatever they have, they will have to spend expenses in amount of tens of millions of rupiah, and they bear all such expenses sincerely. What happened to my relatives' family, may also happen to other families of the Malay community, especially those living in Pontianak. As long as they hold the same ritual of death, then it is also the case with the ritual expenses that they must bear. Perhaps even more, given that a person's social status in society is often retained by the family, whether the person is still alive or dead.

Besides, the value of profit in death, I also found a new understanding of social status in death. Based on the survey conducted on several locations of the Malay community cemetery in Pontianak, I found some social stratification in the cemetery, as a result of the Malay community treatment to the family member's tombs for the purpose of expressing the identity of the deceased during their lifetime in the form of, among others, the different shape of the tombstone for men and women; different economic status in the form of material for tombstones and cover of the grave; different social status in the form of tomb; different events experienced by the deceased during their lifetime in the form accessories installed on the tomb. Based on the phenomena and facts mentioned, I am interested to know the process that applies the death ritual among the Pontianak Malay. Therefore, it is expected to know which death ritual that should be done and maintained, and which should be discontinued.

\section{PONTIANAK MALAY SOCIETY AND RITUAL DEATH}

According Tjahjono as quoted by Budiman, local wisdom is a term often used among scientists to represent a system of values and norms that are 
developed, adopted, understood, and applied to local communities based on understanding and experience in interacting with the environment (Budiman, 2012). In this case, the local wisdom under discussion here is the system of values and norms in the ritual of death compiled, shared, understood and applied by the Malay community of Pontianak based on understanding and experience in interacting between themselves and with the environment. The ritual of death is part of the traditional customs carried out by the Pontianak Malay community, in the moments before death, time of death and after death.

Based on the lexicology, the words mati (die) and kematian (death) are derived from the Arabic word "maut" (الموت) which mean silent, quiet and/or lonely and anything that is silent means death (Ibnu Mandzur, n.d), which are then assimilated into the Indonesian language i.e. mati (v) and kematian (n) meaning "already losing life; no longer alive; does not have life; never lived; unable to do anything; unable to change; no motion or activity; silent or quit; not moving (Dendy Sugono at al., 2008). The words mati and kematian are often equivalent to the word "wafat" (الوفاة) and ajal (الأجل), which are also derived from Arabic. The word wafat means the fulfillment of the lifetime (day, month and year) of someone in the world as may be prescribed (Ibnu Mandzur, n.d); and the word ajal means death and the time limit within the period of validity of something (expired) (Ibnu Mandzur, n.d). In addition, The word mati in the vocabulary of the Pontianak Malay language is also equivalent to the word tewas (die), and pass away and return to the blessing of Allah".

Based on the terminology, death is the end of life, the absence of life in biological organisms. Medically, death is the state of a human who is believed by medical experts to have no more brain function, breathing and/or heart rate, which is punctuated with an indicator that a person is declared dead when the function of the heart-circulatory and respiratory system prove to have stopped permanently, or if the death of the brain has been proved. ${ }^{2}$ Based on the thanatology, death is divided into two stages: (1) Somatic Death, which is marked by respiratory and blood circulation that have stopped, and (2) Cellular Death, which is marked by the death of the cell level. Ibn Mandzur described a person who sleeps with the term light death (الموت الخفيف) and those who died with heavy sleep are called (النوم الثقيل), which states that there are similarities between the condition of the person sleeping and the dead (Ibnu Mandzur, n.d.).

2 See: Pasal 1 huruf g Peraturan Pemerintah RI Nomor 18 Tahun 1981 tentang Bedah Mayat Klinis dan Bedah Mayat Anatomis serta Transplantasi Alat dan/atau Jaringan Tubuh Manusia (LNRI Tahun 1981 Nomor 23; TLNRI Nomor 3195). See also: Pasal 117 UndangUndang RI Nomor 36 Tahun 2009 tentang Kesehatan. 
According to the tradition of the Pontianak Malay community, the families of a deceased person are siblings and relatives. Relatives are the ones who still have a family relationship with the deceased. These relatives are descended from a parent resulting from different gametes. As we know that Pontianak is inhabited by the ethnic Malay majority. Based on population census data of 1990, 2000 and 2010; and a survey of the population in 2005 census by the Central Statistics Agency (BPS) of West Kalimantan Province, it was known that in the next 20 years, there has been a rapid increase in the population of the city of Pontianak, i.e. by 7905 people per year, or $1.43 \%$. This indicates that the City of Pontianak is growing and developing, and it is possible someday it will become a cosmopolitan. In addition, the composition of the population is heterogeneous, with the population of the Malay reaching $26.05 \%$ of the total population of Pontianak city or as many as 144,516 people. Assuming that $100 \%$ of the population ethnic Malay are Muslim, then there are 267,541 people $64.93 \%$ or of the population of Pontianak are Muslim, in addition to other Muslim ethnic groups such as Bugis, Javanese and Madurese.

However, the word Melayu/Malay itself is synonymous with the Islamic religion, in which a Dayak who converts to Islam, will be declared as Malay, as in the case of my father-in-law who comes from ethnic Dayak Punan of the Bungan Jaya village in the upstream Kapuas Hulu, as he has embraced Islam since childhood because he was raised by Muslims, he is regarded as an ethnic Malay, even his son is currently the Chairman of the Malay Youth of Kapuas Hulu. Therefore, basically no matter to which ethnic group a person belongs, when he embraces Islam, he will be considered Malay, and if he comes from the city of Pontianak, he can declares himself as part of the Pontianak Malay Society (Ita Syamtasiyah Ahyat, 2006).

\section{LOCAL WISDOM BEFORE DEATH}

The desire to find out when death will come is reasonable for every human being because he believes that every living creature will surely die. Therefore, there is local wisdom before death among the Pontianak Malay community that I classified into two groups, namely the physical and non-physical signs.

\section{a. Physical Signs}

Physical signs before death are empirical signs experienced or perceived by a person who will die, which are as follows:

3 See: pesantrenawliya.wordpress.com/2010/11/14/tanda-tanda-100-hari-menujukematian-kita/; lihat juga http://shafiqolbu.wordpress.com/2013/09/27/tanda-tandakematian-bagi-orang-islam/\#more-7623 
1) On the 100th day prior to death after Ashr time, the whole body from head to toe will vibrate as if he were shivering;

2) On the 40th day prior to death after the Ashr, the navel of the dying person will twitch, and it is believed when the leaf with his/her name the written on it will fall from the tree located in the Arsy, the angel of death will pick it up and prepare everything related to the death that has been determined. The angel of death will follow this person throughout the rest of his/her life, and sometimes even show his face to the person which will puzzle him/her instantly.

3) On the 7th day before death, for the dying and sick, so he/she does not have the appetite to eat, suddenly he/she will be fond of eating. This is commonly referred to by the Pontianak Malay community with the term "buang tabiat/change of habit".

4) On the 3rd day before death, the dying person will feel a twitch in the middle of the forehead; and the light of his/her eyes begins to disappear; for those who are sick, the nose will slowly flatten; the tip of the ear will become soft and gradually drawn in; and the soles of his/her will slowly soften and difficult to straighten up. Therefore, it is suggested he/she start fasting, so the stomach does not contain feces, making it easier for people to bathe him/her later.

5) On the 2nd day before death, the dying person will normally see and meet with the spirits of those who have died, especially those he/she cares about. $\mathrm{He} / \mathrm{she}$ will feel a twitch in all parts of the forehead; the light of his/her eyes has vanished; for those who are sick, the nose has flattened; the tips of the ear are already soft; and the soles of the feet have softened and difficult to straighten up. Therefore, it is suggested he/she start fasting, so the stomach does not contain feces, making it easier for people to bathe him/her later.

6) On day 1 before death after Ashr time, the dying person will feel a twitch in the back of the head, especially on the crown. This indicates that he will not have time to meet Ashr time of the next day.

\section{b. Non-Physical Signs}

1) Dreaming of broken or loosing teeth

In the Aura bulletin ${ }^{4}$, it was stated that the dream of loosing teeth is one of the most common dreams but also the most difficult to interpret. Many theories about dreaming of losing teeth are circling around. Starting from the dream of teeth falling out one by one or falling on the hand. This dream

4 See: http://www.aura.co.id/life/2-uncategorised/99-menerjemahkan-maknamimpi-yang-paling-umum-2.html 
is not only frightening and shocking, but it often makes people continue to recall it. Interpretation of the meaning of this dream is different. One theory said that a dream of losing your teeth shows that you are very worried about your appearance and the views of others on you. In today's life that gives a high value on beauty, teeth play an important role to create the image. Teeth are also used in seduction and get the attention of the opposite sex. Ranging from a charming smile or fun laugh. Therefore, the dream of losing teeth may reflect the fear of sexual impotence, fear of aging, or other anxieties. Teeth are an important part of the appeal and appearance especially to those concerned with beauty. Therefore, pay attention to the appearance is natural and healthy.

Another interpretation of the tooth loss is likely to come from the fear of embarrassment or fear of looking silly in certain situations. Thus, the dream of tooth loss in this case because you exaggerate your anxiety and restlessness. Teeth are used for biting, tearing and chewing. The role, in this regard, of the teeth symbolizes strength. Tooth dream is likely to come from a sense of helplessness. Are you less powerful lately? Perhaps you have trouble expressing your feelings or your thoughts. You feel frustrated because your voice is not heard. You may feel weak and do not believe in yourself in a particular situation or a particular relationship in your life. This dream indicates that you need to be more assertive and trust on the opinions and self-assessment.

Recent research indicated that menopausal women often dream of teeth. This is related to the possibility of growing old and/or feel unattractive and less feminine. The dream has no teeth or toothless symbolizes malnutrition and can be applied to most people. In Greek culture, dreaming of broken teeth, cavities, or loss of teeth could mean that a family member or close friend will be very ill or even likely to die. According to the Chinese, you will lose your teeth will if you lie. Another assumption said that teeth dreams can symbolize money. This commentary comes from an ancient fairy tale about tooth fairy. If you lose a tooth and put it under the pillow, the tooth fairy will bring money to you.

\section{2) Seeing a Crow around the House}

Crows are considered a sign of difficulties that will arise. because the mystery circling around in the society. A black crow can also be interpreted as a sign of death. When a crow is circling the house, supposedly will be someone dying. Black crow like the carcass so much. So when there is a carcass, the group will immediately flock there. The arrival of a crow in a village or around a house is a sign that in that place there will be a creature that will become a carcass, meaning there will be a person who dies around the place. 
3) Change of Habit, where a person who will die often does unusual things.

"Change of habit reveals a person's behavior that is odd or remarkable; in the view of many people, sometimes he/she behaves strangely, sometimes he/she talks about something remarkable; sometimes without conscious he/she tells old stories.

4) Consciously Meeting Deceased Close Relatives (not in a dream)

A common belief among the Malay community is that 2 days before the death of a person, he/she will be picked up by the deceases close relatives (son, father, mother, uncle, aunt, grandfather and/or grandmother). At this time, usually a person will be able to see and meet with the spirits of people who have died, especially those of their loved ones.

\section{LOCAL WISDOM AT THE TIME OF DEATH}

\section{a. Sakratul maut (Last Moments before Death)}

During Sakratul maut, a dying person will feel cool in the navel and that feel will come down to the waist and climb to the Adam's apple. At that time, that person must continue to recite the shahada (sentences of creed), then be quiet and await the arrival of the angel of death. If another sentence is spoken, because they are invited to talk and / or because they want to leave a will, then they must repeat saying the two sentences of creed. If they are unable and / or difficult to pronounce the two sentences of creed, because the pain of Sakratul maut, the relatives who are around should guide the person to say the two sentences of creed as commanded by Prophet Muhammad (Syaikh Abdul Aziz, 1418H). Once a person has gone through the Sakratul maut, those who are alive are required to do the following things:

1) Rub their right hand on the deceased's face from forehead to chin; when passing by the eye, their palm should be in contact with the deceased's eyelids so as to keep them closed, and when their palm reaches the chin, they should push the chin upward so that the mouth of the deceased can be closed tightly. If the chin is going down again, it must be tied with a cloth (handkerchief) and knotted at the top of the crown.

2) Clean the body of the deceased from dirt and replace the deceased's clothes with clean ones.

3) Tighten the feet of the deceased by tying the big toes together.

4) Laying the deceased's body in a position where the hands are crossed above the navel (as in prayer), and exposed to the direction of Qiblat when the body is laid for prayer (Syaikh Abdul Aziz, 1418H).

5) Cover the entire body of the deceased with a long cloth to cover the private 
parts.

6) Write down the full name of the deceased with his/her parents' names on a piece of paper, and place it next to the body so that the guests who come to mourn can pray for him/her.

7) Remember and talk about all the good things that the deceased ever did during his/her lifetime.

What is done by the Pontianak Malay community, in my analysis, turns out merely to prepare the corpse so that people can proceed with the funeral. To die in a state Husnul Khotimah (good end) is the dream of all Muslims. Therefore, the signs of death in Husnul Khotimah often becomes a topic of conversation among the Pontianak Malay community, while taking care of the body of the deceased. Among the signs of death in Husnul Khotimah, as occurring to Prophet Muhammad's body when he died, namely:

1) Sweating on the forehead. This sign can be seen when someone has just died.

2) Tears. This sign is also seen when when someone has just died as the tears will dry eventually.

3) Eyes remain closed. The deceased's eyes are closed and do not need to be closed by others. Sometimes, there are dead people who cannot close their eyes tightly after death.

4) Lips tightly closed. The deceased's mouth is not open and no saliva coming out of it.

5) Little smile on the face of the deceased. Not a big smile, but the face looks sweet.

6) Bright face. The face does not change in terms of shape and color. Sometimes, the face of a dead person turns black or looks like an animal's. Na'uzubillah.

7) The body does not harden even after a few hours of death. When touched as if the corpse had just died. The joints are supple and easy to bathe.

\section{b. Spreading news of death}

The news of deaths among the Pontianak Malay community is spread through verbal announcements delivered at the nearest mosque from the funeral home, by the deceased's family or the priest and / or administrators of the mosque as well as head of RT. It is announced to the congregation of the mosque and other local Muslim community through the sound system facilities of the mosque. For the relatives, it is usually passed from mouth to mouth, and for those who live far, it is delivered through communications media such as the telephone and text messages. In the Jakarta Betawi community, in addition 
to doing the same as the Pontianak Malay community, they also use a piece of yellow cloth tied around the front of the aisle, and / or the entrance to the funeral home, the place where the body lies in state. Until now, spreading news of death through the mass media, especially the print media, is only done by the Chinese community (Iwan Awaluddin Yusuf, 2005).

Basically the Pontianak Malay community never identify for the bereaved family. The only identity that indicates a deceased family member is the clothes used during prayers and/or feasts in Islamic holy days; and for those who have some money, usually set up tents and provide a chair in front of the house to accommodate the guests who came to mourn. This is somewhat different from the custom of the people other than the Malays, such as Chinese society with a small piece of black cloth pinned to the sleeve or Betawi people who use black clothes, Dayak people wearing lugik cloth belt and sword (Dzulfawati Hassan, 2006).

\section{c. 'Displaying' the body of the deceased}

The Pontianak Malay community has the habit of 'displaying' the body of their deceased family member in the family room or living room. The body of the deceased is treated as if it were ill, lying on the cushion and pandanus mat, as well as covered with a thick blanket. The difference is when the person is ill, the Qur'an and Yasin book are hidden (placed under the pillow), whereas at the moment after death, the Quran or the Yasin book are displayed (on the stomach or on the side of the body). Apart from that, the family also provides a label to the body of the deceased with the full name and the names of his parents (fulan, son of fulan). Therefore, do not be surprised a person's full name is in fact known to the neighbors just after they die.

The purpose of displaying the body in the family room or living room is to give an opportunity for guests to meet the deceased for the last time, so it seems as if the deceased were the host receiving guests at the time. The display process takes place until people responsible for the fardhu kifayah (communal obligation) came to prepare for funeral, because after the body is washed and wrapped in white clot, then there is no more opportunity for the guests to meet the deceased in order to keep deceased's ablution from being nullified.

\section{d. Delaying the Preparation of the Deceased for funeral}

Delaying the process of the preparing the body for funeral often occurs in Pontianak Malay for various reasons as follows: 
1) Lack of equipment and materials required for the preparation process.

2) Lack of people who are expected to lead the entire process starting from bathing the dead, wrapping the body with a shroud, praying for the dead, until reading talqin after burial.

3) Waiting for the family members and relatives of the deceased to attend, especially the parents and / or siblings and / or a biological children who live in another city.

With regard to the desire of the family that is left behind to see the deceased for the last time, they will make every effort to be present at the funeral home within 24 hours, and the delay usually takes no more than 24 hours.

\section{e. Preparing the body of the deceased for funeral}

Preparing the body of the deceased for funeral in the guidance of Islamic law is Fardhu Kifayah, which means that every person shall have competence in the practice, even though the realization is only held by a few people. Over time, preparing the dead body finally becomes a profession carried out by people who are trained for the tasks and they get paid at different rates, depending on the condition of the dead body. In the community of Pontianak Malay, the undertaker is usually the caretaker of a nearby mosque. They are the people who seriously study the fardhu kifayah, while many others only have the knowledge, even some do not know at all.

Similar practice is also prevalent in the Chinese community, where preparation of the dead body for funeral is taken very seriously, which is characterized by the formation of foundations of death, which organizes the care of the dead body in accordance with the amount of savings the deceased had, so as not to burden the family members left behind (Iwan Awaluddin Yusuf, 2005). The preparation of the dead body for funeral is Fardhu kifayah (communal obligation) for Muslims in general and for the people of the Pontianak Malay in particular. The preparation process according the teachings of Islam, includes: 1) bathing the dead body; 2) wrapping the body with a shroud, praying for the dead, and burying the body.

Preparing the body of the deceased for funeral in the community of Pontianak Malay contains some local wisdom as follows:

\section{1) Bathing the body}

At first, the process begins with bathing the dead with equipment and materials available in the house of the deceased along with some fragrance ingredients. At that time when they were still living along the bank of the Kapuas river, the houses were built of wooden floor boards, so that the deceased could be 
bathed in any room that had been cleared of household furniture. Those who bathe the body were usually relatives and the closest relatives of the deceased with their legs sticking out side by side as many as 5 to 7 people. The body is laid on top of their thighs and covered in fabric, each person washes the body parts in front of them while the undertaker of fardhu kifayah prepares water and pours water over the entire body.

Along with the change in the housing material now usually made of concrete (without space under the house), the process of bathing the corpse is no longer done on the thigh of the family members/relatives but it is performed on a table baths (shaped like a boat hull) which is specially constructed to facilitate the process of bathing the corpse. However, there are also several households that are still trying to maintain the process of bathing the corpse using old culture, in which they build wooden floor within their home that will be used for bathing the corpse.

\section{2) Enshrouding the body}

Based on the provisions set by Prophet Muhammad, the number of sheets of fabric to be used by the corpse is 3 pieces of white cloth for men and 5 pieces of fabric for women, not cut to form clothes. It turns out that among the Pontianak Malay community, these provisions developed as follows:

a) The body of the male is enshrouded with 3 pieces of white cloth, which consists of 1 sheet as the first layer cut to resemble the robe; and 2 sheets as a blanket, folded per ply by laying a cloth on the right side on top of the cloth on the left side, tightened and held together with rope made of pieces of white cloth.

b) The body of women is enshrouded with 5 pieces of white cloth, which consists of 1 sheet as the first layer in the form of the robe; 1 sheet as mukena / headscarf; 1 sheet as a sarong; and 2 last sheets as a blanket, folded per ply by laying a cloth on the right side on top of the cloth on the left side, tightened and held together with rope made of pieces of white cloth on seven spots, namely the head, chest, abdomen, waist, thighs, calves and feet.

After the body is enshrouded, if there are family members who wish to see the deceased, the practice common among the Pontianak Malay community is usually to display the dead in the living room, and then take it to the mosque / prayer rooms for prayer.

\section{3) Praying for the deceased}

Despite the absence of legal provisions, the family left behind by the deceased 
among the Pontianak Malay community, usually gives money in sealed envelopes to some of the elders (minimum 10 people) who are involved in the process praying for the deceased.

\section{4) Burying the dead body}

Although there are no legal provisions, the family left behind by the deceased among the Pontianak Malay community, usually provides a some money in a sealed envelope to the grave digger and the caretaker of the cemetery, with hope that the grave will be taken care of properly. Although according to the legal provisions, the dead body should be laid in the grave covered with very thin wall, the Pontianak people tend to use a coffins as the grave, with the following considerations:

a) The position of the grave is not aligned with the location of the tombstone;

b) The possibility of excavating the grave for various purposes, such as forensic or moving to a new location, etc.

Apart from that, the Pontianak Malay community also treat the family grave like the home of the deceased, which includes as follows:

a) The gender of the deceased is retained by differentiating the type of tombstone, in which the round one is for male and the flat for female.

b) On the 100th day, the family of the deceased will replace the tombstone installed with one that is better in accordance with the economic status of the deceased during his/her lifetime, in which the rich will install tombstone made of alabaster or marble decorated with inscription. In fact, some people try to buy land around the grave of the deceased in order to build a home like structure complete with seats, a place for washing feet, and the floor coated with anti-scratch tiles. They do this because they have a culture to visit the grave one day before Eidal Fitr and one day before Eidal Adha. During the visit, they will apologize to the deceased through the mediation of the tombstone.

\section{LOCAL WISDOM AFTER DEATH}

\section{a. Buffet}

After the funeral is done, the family of the deceased normally will invite the guests who come to mourn and participate in the burial process to stop by the funeral home, because food has been prepared. At first, I was surprised, because contrary to the applicable law where the guests who mourn should not burden the bereaved family, because the grief they feel alone is very sad, so is it necessary to serve the guests some food and drink? After conducting 
several interviews and surveys, finally I found an answer to why the family is pleased to provide food and beverage for the guests It is as a sign of gratitude from the family of the deceased to the guests who mourn, for the sympathy and condolences shown by them; and the hope that they will come again on the nights of kendurian (gathering for remembering the dead) and tahlilan (gathering to pray for the deceased by reciting the verses of the Qur'an) to be held on subsequent nights.

\section{b. Tahlilan}

In the community of Pontianak Malay, there is culture of tahlilan (gathering to pray for the deceased by reciting the verses of the Qur'an) held in the evening after isha prayers for three nights in a row after the deceased is buried, in order to accompany the spirit of the deceased to join the new world in the barzah where the spirits gather, followed by tahlilan on the seventh night, with the intention of asking forgiveness of Allah for the deceased at the time when his/ her stomach is broken and reunited with the origins of man, i.e. earth. Then tahlilan is held on the fourteenth night which aims to convey gratitude for the receipt of the deceased spirit among the spirits in the barzah.

On the fortieth night, the family hold tahlilan again with the aim to deliver the farewell for the deceased, marking the end of the period of mourning for the family left behind. The last tahlilan held on the hundredth night is a reminder to the bereaved family to replace the tombstone installed at the grave of the deceased with a better one, according to the socioeconomic status of the deceased during his/her lifetime. The tahlilan event is attended by the families of the deceased and their nearest neighbors and acquaintances, beginning with reading surah al-Fatihah, surah Yasin, tahlil, prayers for the spirits, and ended with dinner.

\section{c. Haulan (Remembering the Day of Death)}

In addition to festivity that has been implemented since the first day the death until the 100th day, the Pontianak Malay also hold haulan repeated every year on the date and month of death of the deceased, by holding tahlilan after evening prayers at the bereaved family's home and it ends with a kendurian.

\section{CONCLUSION}

The Islamic religion is believed by its followers as a religion that is suitable (acceptable) in every age and place, so it can be assimilated and acculturated with local culture that has been understood by the local community before. This principle is used by the Wali Songo and other preachers in an effort to 
preach the Islamic teachings in the archipelago, especially among the Malay community. Based on historical studies, it is known that in the period before Islam spread in the archipelago, the dominant religion was Hinduism. Therefore, it is not surprising that many people found the teachings of Islam are somewhat have a nuance of practice of the Hindu community, especially the Malay community and it has finally rooted and entrenched in the community's culture until today. One of them is the Ritual of Death.

The ritual death in the Malay community is essentially based on the Islamic law (fardhu kifayah), which includes: (1) bathing the dead, (2) enshrouding the dead, (3) praying for the dead, and (4) burying the dead. Even if there are some additions to the rituals of death during the preparation for funeral, it is the result of assimilation and acculturation with the local culture without diminishing the pillars of the fardhu kifayah, and it is developed and preserved within the framework of mutual respect among fellow followers, and with the guests who come to mourn, with regard to providing food and beverage for guests, providing tents and chairs for the guests who are not accommodated in the home, providing an envelope containing money for those involved in preparing the dead for the funeral as a sign of gratitude, providing fragrance in the room to reduce bad smell, writing the full name of the deceased on a piece of paper and placing it next to the corpse because the deceased is often only known by their first names, and a few other extras that aim to speed up and simplify the process of taking care of the deceased.

I personally have yet to find the legal basis either in the Qur'an or Hadith for the death rituals performed by the Pontianak Malay community from the beginning until after the fardhu kifayah process is completed. Therefore, many scholars have been trying to recommend to the Muslims not to continue certain rituals (Syaikh Abdul Aziz, 1418H), such as reading Yasin and tahlil for three consecutive nights on the grave; and continued at the bereaved family's home on the fourth to seventh night; then on the fourteenth, the fortieth, and hundredth night, as well as once a year on the day of the death of the deceased.

\section{REFERENCES}

Ahyat, Ita Syamtasiyah. 2006. Dinamika dan Pengaruh Budaya Melayu di Kalimantan Barat. Prosiding $4^{\text {th }}$ International Conference on Indonesian Studies: "Unity, Diversity and Future";

Algozi, Agus M., (n.d.). Buku Ajar dalam bentuk slide tentang Tanatologi pada Bagian Ilmu Kedokteran Forensik Fakultas Kedokteran Universitas Airlangga. 
Aziz, Syaikh Abdul. 1418H. 148 Fatwa-Fatwa Seputar Jenazah. Riyadh: Maktabah Abusalma al-Atsari.

Budiman, 2012. Keberadaan Kearifan Lokal dalam Pengelolaan Hutan Mangrove: Studi Kasus di Desa Peniti Luar Kecamatan Siantan Kabupaten Pontianak, Tugas Akhir Program Magister, Program Pascasarjana Universitas Terbuka, Jakarta.

Hassan, Dzulfawati Haji. 2006. Upacara Kematian Melanau Likow di Serawak. Samarahan: University Malaysia Serawak.

Ibnu Mandzur, (n.d.) Lisaan al-Arab., Kairo, Daar al-Ma’arif.

Peraturan Pemerintah RI Nomor 18 Tahun 1981 tentang Bedah Mayat Klinis dan Bedah Mayat Anatomis serta Transplantasi Alat dan/atau Jaringan Tubuh Manusia (LNRI Tahun 1981 Nomor 23; TLNRI Nomor 3195).

Sugono, Dendy dkk., 2008. Kamus Bahasa Indonesia, Pusat Bahasa Departemen Pendidikan Nasional, Jakarta.

Undang-Undang RI Nomor 36 Tahun 2009 tentang Kesehatan.

Yusuf, Iwan Awaluddin. 2005. Media, Kematian dan Identitas Budaya Minoritas: Representasi Etnik Thionghoa dalam Iklan Dukacita. Yogyakarta: UII Press, 2005.

\section{Online sources:}

amoli824.net/maklumattambahan1/amalankhurafat.htm;

http://abihulwa.blogspot.com/2012/12/isu-bahasa-apa-itu-buang-tabiat.html http://bahasa.kemdiknas.go.id/kbbi/index.php

http://dininoviartichairlis.blogspot.com/2012/11/suku-melayu-kalimantan-barat $17 . \mathrm{html}$;

http://id.wikipedia.org/wiki/Kematian

http://id.wikipedia.org/wiki/Suku Melayu.

http://kalbar.bps.go.id/index.php?option=com content\&view=article\&id=271\&Itemid $=376$

http://kamusbahasaindonesia.org/mati.

http://shafiqolbu.wordpress.com/2013/09/27/tanda-tanda-kematian-bagi-orang-is$\underline{\text { lam/\#more-7623 }}$

http://www.aura.co.id/life/2-uncategorised/99-menerjemahkan-makna-mimpi-yang-paling-umum-2.html

http://www.pontianakkota.go.id/?q=tentang/letak-geografi-kota-pontianak http://www.pontianakkota.go.id/?q=tentang/suku-bangsa http://www.pontianakkota.go.id/?q=info/agama http://berkah2013.blogspot.com/2013/03/7-tanda-kematian-yang-baik-atau-khusnul.html

http://dear.to/abusalma 
https://www.facebook.com/giuseppemezza.pranacitra/ posts $/ 503743923025153$

https://www.facebook.com/MuhammadIdrusRamli/posts/117823991726182; https:/www.facebook.com/media/set/?set=a.155870187870830.10292.142741209183728\&type $=1$;

pesantrenawliya.wordpress.com/2010/11/14/tanda-tanda-100-hari-menuju-kema$\underline{\text { tian-kita/; }}$

wahonot.wordpress.com/2008/11/19/fatwa-imam-syafii-tentang-kenduri-arwah-tahlilan-yasinan-dan-selamatan; 